\title{
WILLIAM WARWICK WASLEY, 1919-1970
}

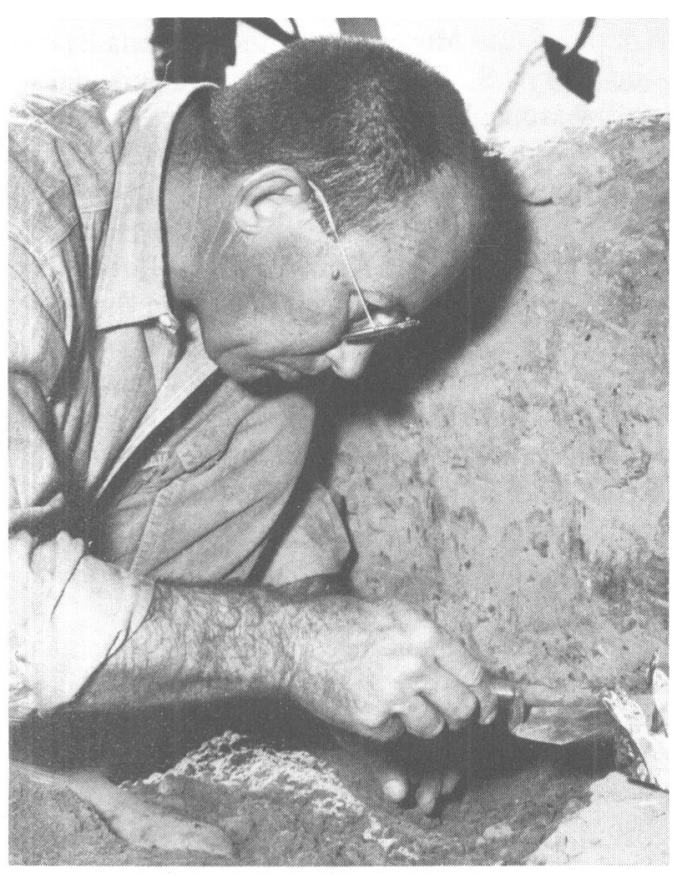

WILLIAM W. WASLEY at Snaketown, October 1964. Arizona State Museum photo by Helga Teiwas
THE GREAT SONORAN DESERT extending south from Arizona's Mogollon Rim to the Rio Yaqui in Mexico is sharply divided by an international political border, while the advent of the Spanish Entradas in this vast region roughly separates the prehistoric from the historic. Fortunately, however, Bill Wasley was determinedly myopic when it came to boundaries; he saw this land and its past as spatial and temporal continua. And well he might, for Bill was a legal citizen of both countries, he was fluent in both English and Spanish, and by virtue of his training and experience, he was as equally at home with the sherds and pithouses of the early Hohokam as he was with the documents and paraphernalia of the Spanish missionaries.

Born in the small Mexican mining community of El Tigre, Sonora, on June 18, 1919, Bill moved within a year with his U.S. parents to the nearby smelter town of Cananea where his father was employed as an engineer. It was here he received his early schooling-mostly from his mother and from correspondence coursesand it was here he received the formative exposure to a Spanish-speaking society that so deeply affected his later professional life. Bill left Mexico to undertake his high school training at the Webb School in California and continued his education at Stanford University and Pomona College before serving in Italy during World War II. It was after the war years that Bill first seriously encountered anthropology, via a correspondence course taught by Clara Lee Tanner of the University of Arizona ("The most important course I ever took"). He soon entered the University of Arizona where he came under the influence of Emil W. Haury and increasingly directed his interests toward southwestern archaeology.

With B.A. in hand (Arizona 1950), Bill embarked on what was the prevailing career pattern of the times, that is, graduate studies interspersed with journeyman fieldwork. He cut his archaeological teeth in the bountiful ruins of the University of Arizona's Archaeological Field School at Point of Pines and proved his worth by being named field foreman for the 1951 season. Classroom studies were continued at both Harvard Universtiy and the University of Arizona with the latter awarding him the M.A. degree in 1953. Then off to Quemado, New Mexico, where he was a field foreman for Harvard's Peabody Museum Upper Gila Expedition. This was followed by a stint in the salvage archaeology trade for the El Paso Natural Gas Company, a field supervisory role in the Lehner Mammoth excavation in southern Arizona, and finally a Ph.D. from the University of Arizona in 1959. His dissertation "Cultural implications of style trends in southwestern prehistoric pottery: Basketmaker III to Pueblo II in west central New Mexico" was largely based on his Quemado work and led to a continuing interest in the theory of pottery analysis. At this point in his career, Bill had accumulated a wealth of experience in a wide variety of southwestern excavations, he had displayed a first class talent for organization, and, in the face of burgeoning 
highway and reservoir construction throughout Arizona, he had developed increasing concern for the protection and salvage of the rich archaeological heritage of the Southwest he loved so well.

Bill had been serving as archaeologist for the Arizona State Museum since 1955 (the first such appointment in the State), but in 1959 his position was expanded to include responsibility for the creation of a state salvage program and the maintenance of a rapidly growing state-wide archaeological survey file. For the next few years, he was intensely involved in a series of Arizona salvage programs. Through contracts between the Arizona State Museum and the Arizona State Highway Department, the National Park Service, and the U.S. Forest Service, Bill personally supervised an astonishing number of excavations. For 3 seasons, he worked in the Painted Rocks Reservoir area near Gila Bend, where he not only carried out the first complete uncovering of a Hohokam platform mound, but where he also got his first taste of historic archaeology in the excavation of a middle nineteenth century Butterfield Stage depot. During this same period, he was busy salvaging a variety of threatened sites over a wide expanse of Arizona-from Lupton in the north to Old Camp Grant in the south and from the Gila River Indian Reservation in the west to the San Carlos Indian Reservation in the east.

But Bill was also concerned about archaeological problems whose solutions required well thought-out investigations. As his staff of trained assistants grew through the early 1960's, he was free to engage in problem-oriented projects of his own choosing and to pursue his long standing interest in prehistoric and historic connections between northern Mexico and southern Arizona. In 1964, he obtained a National Science Foundation grant to dig the Forteleza site near Gila Bend and a year later he was serving as Haury's Assistant Field Director at the massive and complex excavations at Snaketown.

Bill then became involved in a quest which was to prove both a spectacular success and a significant highlight in his research career. The Mexican government had invited him to join their investigators in a search for the remains of Father Eusebio Francisco Kino, the near-legendary Jesuit priest-explorer of Sonora and Arizona. Father Kino's grave, lost to history since his death in 1711, was believed to be in the quiet Sonoran town of Magdalena, presumably beneath a small chapel which long since had been destroyed and forgotten. In a masterful piece of excavating skill, combined with expert sleuthing which rivaled the best of Mr. Holmes, this international team rediscovered Father Kino's grave on May 25, 1966. The find was conclusively verified and today the revitalized and renamed town of Magdalena de Kino has become a center of pilgrimage for all of. Mexico. Few archaeologists are privileged to contribute in such dramatic fashion to the communities in which they toil.

The Father Kino triumph was followed with additional work in northwestern Mexico. With a hand picked crew, and again with the aid of a National Science Foundation grant, Bill completed in 1967 an extensive archaeological survey of lowland Sonora which was primarily undertaken with the hope of shedding light on the elusive Mexican origins of the early Hohokam. At the time of his death, he was preparing these survey findings for publication, as well as writing up results from several other later investigations.

If the Southwest is indeed the premier training ground for archaeologists that it is said to be, then the credit lies with people like Bill Wasley who have so persistently explored and documented the myriad facets of its prehistory. Bill was first and foremost a field man and his many publications and reports will stand as fundamental contributions to the discipline. But he will also be remembered for his effective service in the cause of preserving the past without employing the shovel and trowel. He played a major role in establishing archaeological and historical programs in Arizona, particularly the ongoing and important Highway Salvage Program. Because of his expertise in both archaeology and history, he served by gubernatorial appointment on Arizona's Historic Sites Committee, the Arizona Historical Advisory Commission, and the State Landmarks Committee, being chairman of the latter at his death. He was active as well in a number of professional societies and from 1958 to 1962 served as Assistant Editor of American Antiquity.

A death in the prime of life is always a tragic event, but because Bill was such a physically powerful man, his untimely death seemed doubly shocking to his many friends. He had returned to Mexico-to the land for which he felt such a close affinity. He had returned to the now bustling town of Magdalena de Kino-the scene of his most rewarding professional accomplishment. Bill 
Wasley died in Magdalena de Kino on April 2, 1970, and there he was buried a few score miles from where his life began.

\section{BRYANT BANNISTER Laboratory of Tree-Ring Research University of Arizona}

Bibliography of William W. Wasley

Compiled by the library staff Arizona State Museum

1953

The Late Pueblo occupation at Point of Pines, East Central Arizona. MS, unpublished master's thesis, University of Arizona, Tucson.

(With Alan P. Olson) An archaeological traverse survey in West-Central New Mexico. In Pipeline Archaeology, edited by Fred Wendorf, Nancy Fox, and O. L. Lewis, pp. 256-390. Laboratory of Anthropology, Santa Fe, and Museum of Northern Arizona, Flagstaff.

(With Alan P. Olson) Further excavations at Site LA 2507. In Pipeline Archaeology, edited by Fred Wendorf, Nancy Fox, and O. L. Lewis, pp. 61-65. Laboratory of Anthropology, Santa Fe, and Museum of Northern Arizona, Flagstaff.

(With Alan P. Olson) LA 2506. In Pipeline Archaeology, edited by Fred Wendorf, Nancy Fox, and O. L. Lewis, pp. 51-56. Laboratory of Anthropology, Santa Fe, and Museum of Northern Arizona, Flagstaff.

1957

High way salvage archaeology by the Arizona State Museum, 1956-1957. The Kiva 23:17-19.

Highway salvage archaeology in Arizona. The Kiva 23:4-7.

Review of "The Sawmill Site: A Reserve Phase village, Pine Lawn Valley, Western New Mexico," by Elaine A. Bluhm. American Antiquity 23:202.

The archaeological survey of the Arizona State Museum. Arizona State Museum, University of Arizona, Tucson. (Revised edition, 1964).

$$
1958
$$

Review of "The Glen Canyon survey in 1957," by Robert H. Lister. American Antiquity 24:212.

(With Joe Ben Wheat and James C. Gifford) Ceramic variety, type cluster, and ceramic system in southwestern pottery analy sis. American Antiquity $24: 34-47$.

$$
\text { 1958-59 }
$$

(Assemblies) Notes and News-Sou thwest. American Antiquity, Vols. 24, 25, 26.

$$
1959
$$

(With Emil W. Haury and E. B. Sayles) The Lehner mammoth site, southeastern Arizona. American Antiquity 25:2-30.

Cultural implications of style trends in Southwestern prehistoric pottery: Basketmaker III to Pueblo II in west central New Mexico. Ph.D. dissertation, University of Arizona. University Microfilms, Ann Arbor.

1960

A Hohokam platform mound at the Gatlin site, Gila Bend, Arizona. American Antiquity 26:244-262.

Salvage archaeology on Highway 66 in eastern Arizona. American Antiquity 26:30-42.

Temporal placement of Alma Neck-Banded. American Antiquity 25:599-603.

1961

Review of "The Great Kivas of Chaco Canyon and their relationships," by Gordon Vivian and Paul Reiter. American Antiquity 27:128-129.

Historic site archaeology. Arizonia 2:11-12.

Techniques and tools of salvage. Archaeology 14:283-286.

(With Alfred E. Johnson) Pottery and artifact provenience data from sites in the Painted Rocks Reservoir, western Arizona. Archives of Archaeology 18. Society for American Archaeology and University of Wisconsin Press, Madison.

Review of Table Rock Pueblo, Arizona, by Paul S. Martin and John B. Rinaldo. Hispanic American Historical Review $41: 462463$. 
Review of Black sand, by Harold S. Colton. Hispanic American Historical Review 41:462.

1962

A ceremonial cave on Bonita Creek, Arizona. American Antiquity 27:380-394.

1965

(With Alfred E. Johnson) Salvage archaeology in Painted Rocks Reservoir, western Arizona. University of Arizona, Anthropological Papers 9. University of Arizona Press, Tucson.

1966

(With Alfred E. Johnson) Archaeological excavations near Bylas, Arizona. The Kiva 31:205-253. 1968

(With Blake Benham) Salvage excavation in the Buttes Dam site, southern Arizona. The Kiva 33:244-279.

Ravaged ruins: The destruction of our cultural heritage. The Smoke Signal 18:184-190. Tucson Corral of the Westerners.

Classic Period Hohokam. Unpublished manuscript, revised and expanded from a paper read at the 31 st Annual Meeting of the Society for American Archaeology, Reno, Nevada, 1966. 